\title{
TU/e EnмHONEN

\section{Improving physics teaching materials on sound for visually impaired students in high school}

\section{Citation for published version (APA):}

Toenders, F. G. C., de Putter-Smits, L. G. A., Sanders, W. T. M., \& den Brok, P. (2017). Improving physics teaching materials on sound for visually impaired students in high school. Physics Education, 52(5), [055006]. https://doi.org/10.1088/1361-6552/aa7969

DOI:

10.1088/1361-6552/aa7969

Document status and date:

Published: 01/09/2017

\section{Document Version:}

Accepted manuscript including changes made at the peer-review stage

\section{Please check the document version of this publication:}

- A submitted manuscript is the version of the article upon submission and before peer-review. There can be important differences between the submitted version and the official published version of record. People interested in the research are advised to contact the author for the final version of the publication, or visit the $\mathrm{DOI}$ to the publisher's website.

- The final author version and the galley proof are versions of the publication after peer review.

- The final published version features the final layout of the paper including the volume, issue and page numbers.

Link to publication

\section{General rights}

Copyright and moral rights for the publications made accessible in the public portal are retained by the authors and/or other copyright owners and it is a condition of accessing publications that users recognise and abide by the legal requirements associated with these rights.

- Users may download and print one copy of any publication from the public portal for the purpose of private study or research.

- You may not further distribute the material or use it for any profit-making activity or commercial gain

- You may freely distribute the URL identifying the publication in the public portal.

If the publication is distributed under the terms of Article 25fa of the Dutch Copyright Act, indicated by the "Taverne" license above, please follow below link for the End User Agreement:

www.tue.nl/taverne

Take down policy

If you believe that this document breaches copyright please contact us at:

openaccess@tue.nl

providing details and we will investigate your claim. 


\title{
Improving physics teaching materials on sound for visually impaired students in high school
}

\author{
Frank G.C. Toenders, Lesley G.A. de Putter - Smits, Wendy T.M. \\ Sanders, and Perry den Brok \\ Eindhoven School of Education - TU Eindhoven
}

\begin{abstract}
When visually impaired students attend regular high school, additional materials are necessary to help them understand physics concepts. Time for teachers to develop teaching materials for such students is scarce. Visually impaired students in regular high school physics classes often use a braille version of the physics textbook. Previously, we evaluated the physics learning environment of a blind high school student in a regular Dutch high school. In this research we evaluate the use of a revised braille textbook, relief drawings, and 3D models. The research focussed on the topic of sound in grade 10 .
\end{abstract}

\section{Introduction}

It is known that visually impaired students often struggle in getting an education, especially in the sciences (Boswinkel et al.,2012;Dunkerton,1997). Additional materials are recommended when teaching science to the visually impaired (Dunkerton,1997, e.g.). In our previous research we concluded that adaptation of the braille physics textbook is necessary, since figures and graphs are inaccessible to the visually impaired (Toenders, De Putter, Sanders, \& Den Brok,-). Research has shown that tactile materials and audible graphs could be used to aid the teaching of physics to visually impaired students (Supalo, Humphrey, Mallouk, David Wohlers, \& Carlsen,2016;Zebehazy \& Wilton,2014). Research on teaching STEM subjects to the visually impaired is scarce (Erwin, Perkins, Ayala, Fine, \& Rubin,2001;Azevedo \& Santos,2014) and has been limited to studying individual possible additions to classroom materials (use of relief drawing boards, tangible graphs) that teachers themselves need to design and create.

The research presented here is part of a larger project that focusses on the design and evaluation of an approach to teach a complete physics subject to a visually impaired student, involving the student, teachers, and publisher of educational materials. In this article we will describe the design and use of an adapted braille textbook, relief drawings, and 3D printed models in teaching the physics of sound to a visually impaired student. This choice was made upon suggestion from the physics teacher involved in this study. He considered the number of graphs involved in studying sound an issue in teaching the blind. 


\section{Existing materials for teaching science to visually impaired students}

The development of mathematical skills in visually impaired students, needed to study STEM subjects, depends on the natural ability, the remaining vision, the age at which the student became blind, and the environment the student grew up in (Boswinkel et al.,2012). The learning environment the student experiences is one of the few factors that can be influenced and optimised, and therefore is the most important factor in developing these skills. Visually impaired students can study STEM subjects, if there is individual assistance and if suitable teaching materials are available (Erwin et al.,2001;Adam \& De Groot,2006). In our previous research, the braille physics textbook was in need of revising to eliminate use of text referring to visible objects (pictures, graphs and so on) (Toenders et al.,-). 3D models can be a tool for teaching visually impaired students physics, when they are accompanied by curricular material that incorporates their use. However, no examples of teaching a coherent (part of a) physics curriculum are available.

Since the arrival of 3D printing technology, 3D models are relatively easy to come by. 3D printing is a technique where the model is built up layer after layer (Voigt \& Martens,2006). It sprouted from the desire in industry to be able to create prototypes of new products quickly and cheaply (Bradshaw, Bowyer, \& P.Haufe,2010). 3D printed models also have an added value in (special needs) education (Buehker, Comrie, Hofmann, McDonald, \& Hurst,2016), especially for children who were born blind (Jafri \& Ali,2015). 3D models can help discover and experience public spaces and buildings (Voigt \& Martens,2006), read sheet music (tactile stave notation), play games (rubic's cube, sudoku, four-in-a-line), and book illustrations (picture books, tactile graphics) (All about 3D printing,2017). Research into the use of 3D models for visually impaired students is however scarce, and seems limited to the use tactile graphs (Voigt \& Martens,2006;Buehker et al.,2016).

Despite the increased accessability of 3D printing to the general public, the actual use of the printer is not straightforward. Designing and producing a 3D model requires specific knowledge on for instance material properties (Voigt \& Martens,2006) and print error analyses (Buehker et al.,2016). This kind of knowledge can be found with mechanical engineers or industrial design professionals. For high schools teachers it would be preferable if print-ready 3D models designed for the current science curricula were available (Buehker et al.,2016). Boswinkel and Van Leeuwen (2008) suggest that teachers would be encouraged using 3D models when the teaching materials are available alongside the 3D printable models. Especially when these assignments are also pertinent to regular students.

Additional tools for teaching mathematics to visually impaired students were designed for Dutch high schools. The mathematics toolbox contains materials that can be used in class, such as an adapted ruler and protractor triangle, a relief algebra- and graph book and Wikki Stix, that can be bend in any desired shape to illustrate the graph in question. Such a maths toolbox costs around 300 British pounds or 350 American dollars and requires tutoring for teacher, student and parents to learn how to work with it (Bartiméus,2016). The toolbox also contains 3D models representing the spacial arrangement of for instance the cube, prism and pyramid that are part of the mathematics curriculum. From evaluation studies by van Boswinkel and Van Leeuwen (2008) it seems the maths toolbox is not used much in class. The reasons for this are not reported in this study, but an explanation could 
be that the content is not matching the curricular materials the teacher uses (Boswinkel \& Van Leeuwen,2008). A lesson plan contains elements that match and are logically following one another, where the additional materials are integrated seamlessly in the lesson content (Van den Akker \& Thijs,2009).

Summarizing, visually impaired students can study mathematics more successfully using tactile materials. Key seems to be the availability of supporting curriculum materials, to ensure their use. For physics such materials are not available, nor is there a tested physics learning environment (books, materials, experienced teachers) for visually impaired students. Therefore, the present study will focus on the design of a coherent part of a physics curriculum for visually impaired students. Our general research question is:

What (additional) teaching materials can aid visually impaired students to learn the concept of sound?

This research will focus on the physics taught in grade 10 in Dutch high schools, since it is still an obligatory subject in this grade.

\section{Method}

\section{Participants}

This research is qualitative in nature. It was conducted in one Dutch high school that accommodated a year 10 visually impaired student in a regular physics class of 28 for the first time in the school's history. The school is situated in the middle of the Netherlands and is attended by approximately 1100 (regular) students. The teacher, the mentor, and the visually impaired student all voluntarily agreed to participate in this research. The parents gave their consent for the student to participate in the research project.

Visually impaired student. She is 14 years old and has a remaining vision of $0.5 \%$. She can determine the difference between day and night but in practice her vision is negligible. The student has accepted that she is blind and does not mind talking about it.

Physics teacher. He (36) has been a physics teacher for 11 years and has no previous experience with teaching visually impaired students.

Mentor. He (34) has been teaching geography for four years. Besides the student's mentor, he is also her geography teacher. No previous experience teaching visually impaired students.

\section{Design process}

In the design process for the additional teaching materials the phases of the ADDIEmodel (Branson, Rayner, Cox, Furman, \& King,1975) were executed.

- phase 1; analysis

- phase 2 ; design

- phase 3; development 
- phase 4; implementation and evaluation

The focus of this article is on phase four: the implementation and evaluation.

During the orientation phase the limitations the physics teacher experiences in class, that formed the central focus of this research, were identified. This was reported on in a previous article (Toenders et al.,-). The design phase consisted of improving the teaching materials available, based on the outcomes of the previous phase. Contacts within Thinkable and the Accessibility Association - an institute for expertise and research in ICT accessibility- were involved in this phase. To aid with the $3 \mathrm{D}$ models, the faculty of Industrial Design at the Eindhoven University of Technology was approached. The design focussed on the textbook sections audible oscillations and the speed of sound of the chapter on sound. The publisher of the braille physics textbook, Dedicon was approached to incorporate the design, which they agreed to within their limitations.

The implementation and evaluations consisted of a trial run of the new materials. The materials were provided to the physics teacher sufficient time in advance. The classes taught with the materials were observed. These observations led to in-depth questions about the effect of the new materials. These questions were used in a semi-structured interview with the three participants: the teacher, mentor, and visually impaired student.

\section{Instruments and analysis}

All lessons observed were recorded using two video recorders: one pointing at the electronic board (Smartboard) and one at the visually impaired student. The recordings were combined into split screen recordings. During the observations notes were taken on the problems occurring per learning activity, such as struggles with the adapted braille textbook, tactile graphs, and 3D models. From these observations more in-depth questions on the use of the adapted and added materials were identified, which were then used in a semi-structured interview with the three participants.

The semi-structured interviews were recorded. A minute to minute transcript was made from these recordings. The transcripts were then analyzed to be able to evaluate the materials that were designed.

\section{Adaptations and design of materials to teach physics to a visually impaired student}

The sections in the braille textbook on audible oscillations and the speed of sound were revised. Dedicon printed the adapted braille versions of the paragraphs and assembled them in one ring binder. Four 3D models were designed to assist in the understanding of the concepts frequency, period, high versus low keys, loud versus mellow keys, dampened oscillation and a graph of oscillation in time.

\section{Adapted paragraphs in the visually impaired textbook}

Changes to the braille textbook in the sections on audible oscillations and the speed of sound were suggested by the first researcher in close conference with an expert on pedagogical content knowledge (third author). The adapted text was subsequently printed by Dedicon. The changes consisted of: 
The number of words was reduced with $18 \%$ from 8445 to 7176 by removing irrelevant content, such as descriptions and referrals to inaccessible figures, formulas or tables, irrelevant assignments and undoable experiments.

Essential figures were ordered as relief drawings. They are depicted in the Appendix.

To match the perception of the visually impaired student or to circumvent the use of a figure, inaccessible questions or exercises were rephrased. The researcher tried to stay as true to the original question as possible. An example of rephrasing a question is: [original] "On the next picture you can identify seven clocks. What is the difference between the sound produced by each of these clocks?" [rephrased] "The bell of a church tower is a lot bigger than that of a living room clock. The shapes are the same. What is the difference between the sounds of these two clocks?".

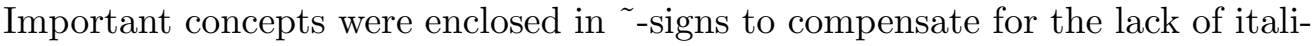
cisation options braille.

The main headings in the revised braille book were labelled with black on white lettering, to indicate to the teacher and fellow student where in the textbook the visually impaired student was reading.

A small music box, similar to one that was referred to in one of the questions, was added to the study materials, for the visually impaired student to experience its operation. 


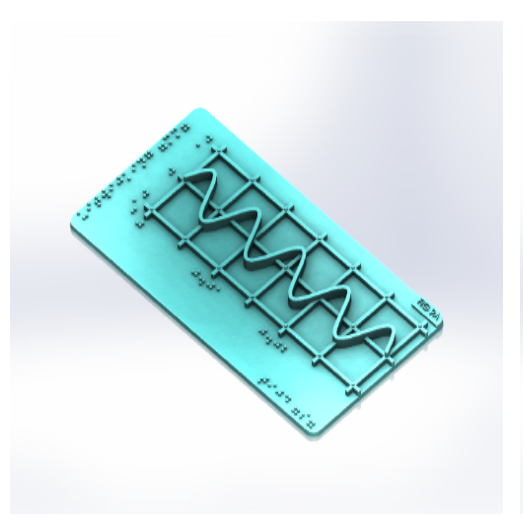

Figure 1. Model 1a

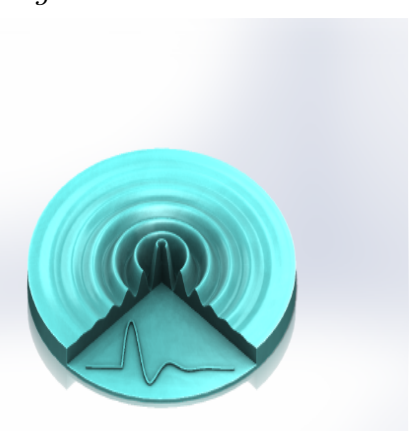

Figure 4. Model 2

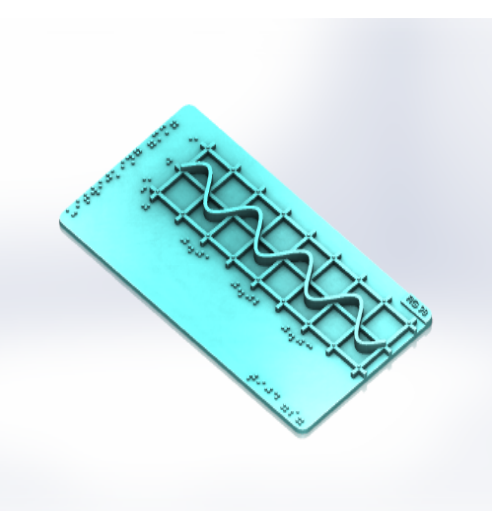

Figure 2. Model 1b

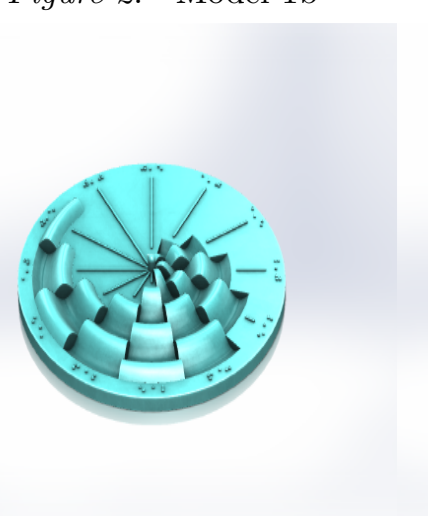

Figure 5. $\quad$ Model 3

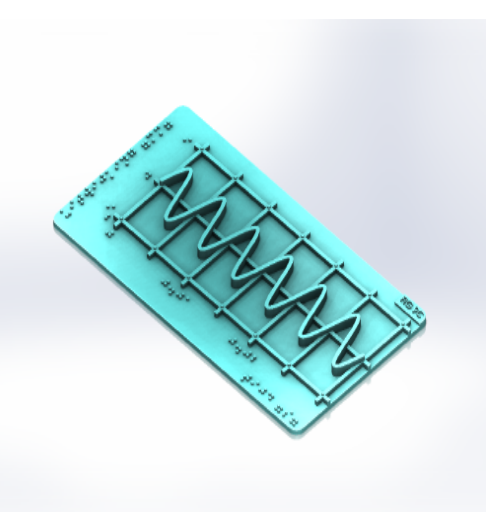

Figure 3. Model 1c

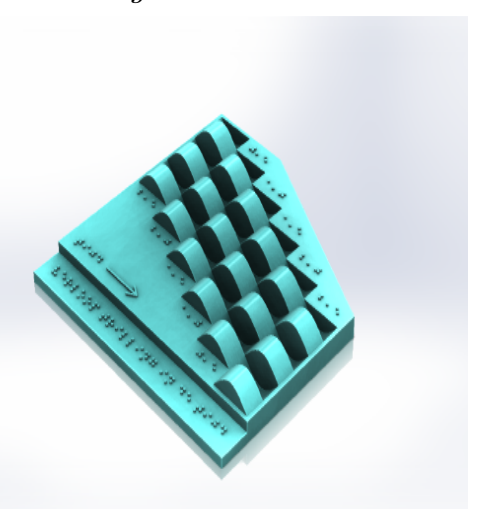

Figure 6. Model 4

\section{Additional materials: $3 D$ models}

Four 3D models were designed to clarify the concepts sound and oscillations to the visually impaired student. They are depicted in Figure 1 to 6 . These models were printed using VeroWhite Plus and Polyactite. Technical specifications of the models, printers and filaments can be obtained from the corresponding author. After printing, the braille on the models was labelled in plain text to facilitate the teacher and fellow student.

Model 1a, 1b, and 1c (Figure 1, 2, and 3) consist of three configurations depicting a sound wave that can be used with the concepts frequency, period, high versus low keys and loud versus mellow keys. The y-axis shows the amplitude in millimeter, the $\mathrm{x}$-axis shows time in seconds. This model belongs to an exercise from the textbook: Which graph represents the highest, the lowest and the loudest key?

Model 2 (Figure 4) can be used to explain dampened oscillation. The dampening is also shown in the z-plane. This model clarifies the phenomenon that a (sound) wave moves in all directions, by using cilindric shapes .

Model 3 (Figure 5 ) and model 4 (Figure 6 can be used to explain the shape of an oscillation in time. The cylindric model is divided into twelve equal parts. Each part has 


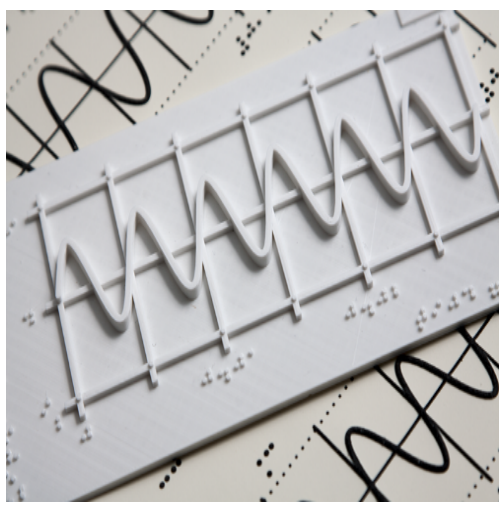

Figure 7. 3D model (PLA) and relief drawing

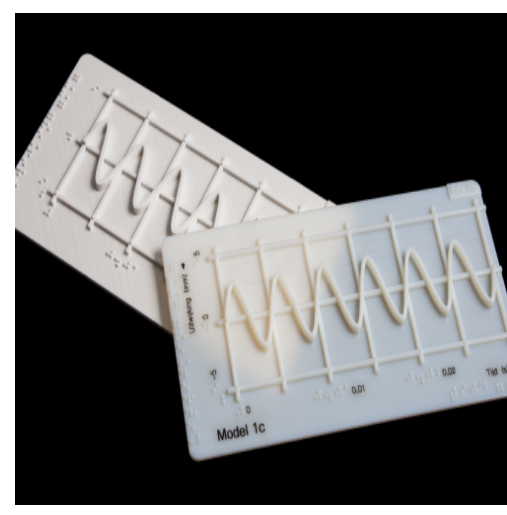

Figure 8. Two types of filament

moved halve a phase on the time axis. By feeling clockwise the student can identify 0,0 0,5 - 1,0 - 1,5 - 2,0 - 2,5 - 3,0 - 2,5 - 2,0 - 1,5 - 1,0 - 0,5 complete oscillations respectively, before arriving at the starting point. Again, the cylindric shape indicates to the student that a (sound) wave moves in all directions. Model 4 is conceptually the same as model 3, except that the oscillation moves from left to right here.

\section{Evaluation of the adapted and designed materials for teaching sound to a visually impaired student}

The redesigned materials and their learning goals were discussed with the teacher prior to the observed classes. The teacher was provided with a teacher manual containing the learning goals as discussed as a reference. The teacher prepared the lessons taking the redesigned materials into account. Prior to the observed classes the teacher provided the visually impaired student with the redesigned paragraphs. During class the teacher used model one, model two, the music box and the relief drawing. All additional materials were used whilst making exercises from the textbook.

Experiences with the $3 D$ models

One of the figures from the textbook was converted to a relief drawing and to a 3D model (see Figure 7). The 3D model was printed using two different filaments (Figure 8). 
The visually impaired student indicated she could feel more detail in the relief drawing than the 3D models. She preferred the 3D model, because she prefers 3D over 2D. She could read the braille printed on the model. She indicated that she did not have a preference for one filament over the other. She did indicate that her sensitive fingers found the cheaper PLA filament rough and edgy.

She could not make sense of the graphs by herself, in that she could not determine the period of the oscillation. She stated she has had little experience in reading and understanding graphs. With some clues she determined the period of the oscillation.

Model 2 (figure 4) depicts a dampened oscillation. Unaided, the visually impaired student could not determine what it was exactly she was feeling. Visually impaired student: "It is a circle. Some kind of spiral that starts on the edge and spirals inwards?". The student had the model placed at a wrong angle in front of her. This explains why she could not sense a dampened oscillation. The student was also unable to comprehend models 3 (figure 5) and 4 (figure 6), just by touching them. The models were not self-explanatory.

From the test it became apparent that the symbol for number was missing in the braille tekst. This led to 0.5 being read as J.E. Another drawback using the models was the spatial orientation of the model, how to keep it the right side up. Tilting the model changed the meaning of the model and the meaning of the braille script. The braille script needed to be printed in a large enough space to be interpretable. The models moved easily on the surface, making it difficult for the student to use them consistently. Making the 3D models from scratch was time consuming, and as was confirmed by the teacher, outside the normal teaching expertise.

The teacher was very positive about the effect the materials had. They improved understanding of the concepts. According to him, it was just a matter of time before both he and the visually impaired student would be used to the additional materials such as the relief board and the 3D models.

\section{Conclusions and discussion}

This research has shown that redesigning of and adding to braille study materials improved the learning experiences and made physics more accessible for visually impaired students in regular high schools. This is inline with findings by Erwin et al. (2001), and Adam and De Groot (2006). By omitting irrelevant materials, adapting figures and adding 3D models more insight was gained on how physics can be taught to visually impaired students.

Limitations experienced when teaching physics to a visually impaired student were found to be not only in the teaching materials themselves, such as in inaccessible drawings or referrals to pictures and graphs, but also in the amount of time the teacher has in lesson preparation and teaching, and in the social setting the learning of the visually impaired student can take place.

Adapting the braille textbook has shown both improvement on the learning of physics as well as limitations. The material cannot be adapted too much, in order for the visually impaired student to be in sync with her fellow students. Adapting the textbook 
will have to be done in more than one design cycle, since new drawbacks of the redesign were found in for instance how visually impaired students read relief graphs. The student and teacher were both satisfied with the new assignments and relief drawings. These aided the student to experience physics on a more intensive as well as applied level.

When adapting braille books using the findings of this research, the focus could be placed on the elimination of irrelevant tekst and pictures. By that alone, the braille tekst book in this study was reduced with $18 \%$. Another important factor for review are assignments that emphasize visible objects or events. These assignments have to be adapted by a physics educationalist to draw on the same physics principles, but refer to different examples or objects that are meaningful to visually impaired students, for instance those that can be explored by touch. Some relevant printed tekst will need to be provided on braille textbook pages and relief drawings, to ensure a fellow student or teacher can help the visually impaired student explore and understand the text and drawings correctly. If not, even though the materials are adapted, they can still lead to misconceptions in physics. In all it can be concluded that redesigning physics textbooks for visually impaired students is complex.

When designing 3D models to aid physics teaching, it has become apparent that the orientation of the 3D model on the table is important for the visually impaired student to capture its intention. The aid of a teacher or fellow student is required for the visually impaired student to use the model correctly. When the model is not positioned correctly, both the braille on the model as well as the intention of the model can be misread. The interpretation of the model needs to be checked by the teacher to ensure no misconceptions arise using the model.

3D model design is not something teachers learn during their training. Although websites exist were 3D models for educational purposes are publicly shared, it is not within the teachers' expertise to chose, adapt and print the necessary model for the next concept to be taught. More research and mostly development of 3D models of physics concepts is needed to make this accessory widely available to visually impaired students of physics.

In all, visually impaired students need more time from the teacher to be able to learn physics in high school than the regular students. Although aided by improved materials, the way a visually impaired student develops knowledge in physics will be different from the fellow students, and thus requires more time from the teacher. Adapting the study materials leads to a better understanding of physics, however, as (Millar,1997) and (Van Leendert,2008) state, a visually impaired student needs more time to process new information, since touch and sound are successive processes in the human brain (as opposed to sight and sound). 
IMPROVING PHYSICS TEACHING MATERIALS FOR VISUALLY IMPAIRED STUDENTS10

\section{References}

Adam, W., \& De Groot, M. (2006). Eindverslag project newton (Tech. Rep.). Zeist, Gouda: Bartimus, Coornhert Gymnasium.

All about 3D printing. (2017, april). 10 ways 3d printing supports the blind. https://all3dp.com/3dprinting-supporting-blind-people/.

Azevedo, A. C. de, \& Santos, A. C. F. (2014). Teaching optics to blind pupils. Physics Education, $49(4), 383-387$.

Bartiméus. (2016). Wiskundekist voor braille- en zeer slechtziende leerlingen. http://www.eduvip.nl/cms/files/wiskundekist-voor-braille.pdf; last checked april 1st 2016.

Boswinkel, N., Van Herpen, E., Janssen, C., Kroesbergen, E., Van Leendert, A., Sluis, I. V. D., et al. (2012). Passende perspectieven rekenen; profielschetsen (Tech. Rep.). Enschede: Stichting Leerplan Ontwikkeling.

Boswinkel, N., \& Van Leeuwen, A. (2008). Doe maar gewoon een exploratief onderzoek vanuit een leerplankundig perspectief (Tech. Rep.). Enschede: Stichting Leerplan Ontwikkeling.

Bradshaw, S., Bowyer, A., \& P.Haufe. (2010). The intellectual property implications of low-cost 3d printing. Scripted, 7(1), 5-31.

Branson, R. K., Rayner, G. T., Cox, J. L., Furman, J. P., \& King, F. (1975). Interservice procedures for instructional systems development. executive summary and model (Tech. Rep.). DTIC Document.

Buehker, E., Comrie, N., Hofmann, M., McDonald, S., \& Hurst, A. (2016). Investigating the implications of 3d printing in special education. Transactions on Accessible Computing, 8(3), $11.1-11.28$

Dunkerton, J. (1997). The science entitlement of visually impaired students at gcse and a-level: A national survey (1992-1994). British Journal of Visual Impairment, 15(1), 15-21. Available from http://dx.doi.org/10.1177/026461969701500104

Erwin, E., Perkins, T., Ayala, J., Fine, M., \& Rubin, E. (2001). You dont have to be sighted to be a scientist, do you? Issues and outcomes in science education. Journal of Visual Impairment \& Blindness, 95(6), 338-352.

Jafri, R., \& Ali, S. A. (2015). Utilizing 3d printing to assist the blind. In 2015 international conference on health informatics and medical systems (hims 2015) (p. 55-61).

Millar, S. (1997). Theory, experiment and practical application in research on visual impairment. European Journal of Psychology of Education, 12(4), 415-430.

Supalo, C. A., Humphrey, J. R., Mallouk, T. E., David Wohlers, H., \& Carlsen, W. S. (2016). Examining the use of adaptive technologies to increase the hands-on participation of students with blindness or low vision in secondary-school chemistry and physics. Chemistry Education Research and Practice, 17(4), 1174-1189. Available from http://dx.doi.org/10.1039/C6RP00141F

Toenders, F., De Putter, L., Sanders, W., \& Den Brok, P. (-). Analysing the physics learning environment of visually impaired students in high schools. $t b d$.

Van den Akker, J., \& Thijs, A. (2009). Leerplan in ontwikkeling. Enschede: SLO.

Van Leendert, A. (2008). Het juiste gevoel. Nieuwe Wiskrant, 28(2), 4-9.

Voigt, V., \& Martens, B. (2006, September). Devolpment of 3d tactile models for the partially sighted to facilitate spatial orientation. In Conference proceedings (Vol. 24, p. 366-370). Athens, Greece.

Zebehazy, K. T., \& Wilton, A. P. (2014). Straight from the source : Perceptions of students with visual impairments about graphic use. Journal of Visual Impairment \& Blindness, 108(4), $275-286$. 